\title{
BENTUK DUKUNGAN KELUARGA DALAM MENJAGA KESEHATAN MENTAL LANSIA
}

\author{
Dian Hardianti ${ }^{1}$, Jamaluddin Hos $^{2}$, Sarpin $^{3}$ \\ ${ }^{1}$ Jurusan Ilmu Kesejahteraan Sosial FISIP Universitas Halu Oleo Kendari, Indonesia \\ ${ }^{2}$ Jurusan Sosiologi FISIP Universitas Halu Oleo Kendari, Indonesia \\ ${ }^{3}$ Jurusan Sosiologi FISIP Universitas Halu Oleo Kendari, Indonesia \\ dianhardianti100198@gmail.com
}

\begin{abstract}
This study aims to determine the condition of mental health of the elderly and forms of family support in maintaining mental health of the elderly in the Kadia Village, Kadia District, Kendari City. The research method used is using qualitative descriptive research methods, research data collection techniques used are interviews, observation, and documentation, the informant of this research is the elderly family includes the support of biological children totaling 3 people, son-in-law totaling 3 people, grandchildren totaling 1 person, and the elderly themselves, amounting to 10 people, the total number of informants totaled 17 people, the source of data in this study are primary data and secondary data, while the data analysis technique is data reduction and presentation of conclusions to find findings related to problem statement written down. From the results of research conducted obtained that there are several mental health conditions that have been experienced by the elderly, namely having feelings of anxiety, easily feeling tired, easily feeling offended, and those who have a healthy mental but with such health conditions, families have a good form of support for elderly Elderly get information support, assessment support instrumental support, and good emotional support. Strong family ties will greatly help the mental health of the elderly to deal with problems in daily life. The better the support from family, the elderly can be as long as possible efficient because the support of those closest to them can provide the spirit of life for the elderly.
\end{abstract}

Keywords : elderly, family, mental health.

\begin{abstract}
ABSTRAK
Penelitian ini bertujuan untuk mengetahui kondisi kesehatan mental lansia dan bentuk dukungan keluarga dalam menjaga kesehatan mental lansia di Kelurahan Kadia Kecamatan Kadia Kota Kendari. Adapun metode penelitian yang digunakan yakni menggunakan metode penelitian deskriptif kualitatif, teknik pengumpulan data penelitian yang digunakan yaitu wawancara, observasi, dan dokumentasi, informan penelitian ini adalah keluarga lansia mencakup dukungan anak kandung yang berjumlah 3 orang, menantu yang berjumlah 3 orang, cucu yang berjumlah 1 orang, dan lansia itu sendiri yang berjumlah 10 orang, total jumlah informan keseluruhan berjumlah 17 orang, sumber data dalam penelitian ini yaitu data primer dan data sekunder, adapun teknik analisis data yakni reduksi data penyajian data dan penarikan kesimpulan untuk mencari temuan yang berkaitan dengan rumusan masalah yang dituliskan. Dari hasil penelitian yang dilakukan diperoleh bahwa ada beberapa kondisi kesehatan mental lansia yang telah dialami yakni memiliki perasaan kecemasan, mudah merasa kelelahan, mudah merasa tersinggung, dan adapula yang memiliki mental yang sehat namun dengan kondisi kesehatan yang demikian, keluarga memiliki bentuk dukungan yang baik terhadap lansia. Lansia mendapatkan dukungan informasi, dukungan penilaian dukungan instrumental, dan dukungan emosional yang baik. Ikatan kekeluargaan yang kuat akan sangat membantu bagi kesehatan mental lansia untuk menghadapi masalah dalam kehidupan sehari-hari. Semakin baik dukungan dari keluarga, maka lanjut usia dapat selama mungkin berdaya guna karena dukungan dari orang-orang terdekat dapat memberikan semangat hidup bagi lansia.
\end{abstract}

Kata-kata Kunci: lansia, keluarga, kesehatan mental. 


\section{PENDAHULUAN}

Kesehatan merupakan hal yang penting atau sentral demi keberlanjutan kehidupan yang memadai, sehat sendiri memiliki makna dimana keadaan yang sejahtera seimbang baik jasmani atau rohani yang memungkinkan seseorang hidup produktif secara sosial maupun ekonomi. Undang-Undang No. 23 Tahun 1992 tentang Kesehatan pada pasal 19 bahwa kesehatan manusia usia lanjut diarahkan untuk memelihara dan meningkatkan kesehatan dan kemampuannya agar tetap produktif, serta pemerintah membantu penyelenggaraan upaya kesehatan usia lanjut untuk meningkatkan kualitas hidupnya secara optimal.

Kesehatan lansia merupakan suatu hal yang patut untuk diperhatikan. Kesehatan yang dimaksud adalah pada kesehatan baik secara fisik, sosial, maupun emosional, sebagaimana disebutkan oleh (WHO 2013). Menurut Hardywinoto dan Tony (dalam Nurmalasari, 2010) kesehatan lanjut usia meliputi kesehatan badan, rohani dan sosial sehingga bukan hanya keadaan yang bebas dari penyakit, cacat dan kelemahan.

Lanjut usia merupakan bagian dari proses pertumbuhan dan perkembangan yang akan dialami oleh setiap orang. Proses ini dimulai sejak terjadinya konsepsi dan berlangsung terus sampai mati. Pada proses menua, terjadi perubahan-perubahan yang berlangsung secara progresif dalam proses-proses biokimia, sehingga terjadi perubahanperubahan stuktur dan fungsi jaringan sel/organ dalam tubuh individu (Nugroho, 2009).

Pada proses menua terjadi berbagai hal yang mengakibatkan berbagai fungsi tubuh menurun seperti penurunan fisik, psikologis, maupun sosial yang saling berinteraktif satu sama lain serta memiliki potensi menimbulkannya masalah kesehatan mental karena adanya perasaan tak berdaya. Kesehatan mental merupakan masalah yang sangat terkait dengan lansia, dan tidak boleh dianggap remeh karena sehat mental merupakan aspek pentik bagi lansia itu sendiri (Zulkarnain dalam Amelia dkk, 2017).

Kesehatan mental menunjukkan kemampuan untuk mengatasi masalah secara efektif dan mengelola stress kehidupan dalam upaya untuk mencapai keadaan emosional yang seimbang. Lanjut usia memiliki keuntungan lebih dari pada kelompok usia lainnya dalam mengatasi pemecahan masalah berdasarkan banyak pengalaman yang dialami bertahun-tahun. Hal ini tidak berarti bahwa gangguan mental tidak menjadi masalah dikalangan lanjut usia (Eliopoulus, 2003).

Terutama lansia yang ada di Kelurahan Kadia, Kecamatan Kadia, Kota Kendari dengan berjumlah sebanyak 120 orang (Lembaga Swadaya Masyarakat Al Jannah, 2019) yang tinggal dengan keluarganya, keluarga yang dalam artian merupakan suatu unit kelompok kecil dalam masyarakat yang sangat berpengaruh dalam membangun pola interaksi dalam keluarga untuk tetap menjaga kondisi kesehatan mental, 
memberikan bentuk dukungan keluarga dalam menjaga kesehatan mental lansia bilamana lansia telah mengalami kondisi kesehatan mental yang rendah atau gangguan mental.

Kelompok usia rentan seperti anak dan lanjut usia sangat membutuhkan dukungan keluarga untuk mengatasi masalah yang dihadapi (Tuwu et al., 2020). Menurut Cutrona, 1994 menyatakan bahwa individu yang memperoleh reward dalam suatu hubungan sosial akan menampakkan tingkat kesehatan lebih baik tanpa memperhatikan derajat tekanan yang dialami. Selain itu, bantuan yang diberikan dengan penuh kasih sayang (affectionate assistance) dari orang lain diakui dapat memberikan suatu tenaga penyangga (buffer) melawan tekanan dan stres.

Oleh karena itu keluarga dalam menjaga kesehatan mental lansia dengan memberikan bentuk dukungan yakni berupa dukungan informasi, dukungan penilaian dukungan instrumental, dan dukungan emosional untuk merawat dan menjaga kesehatan lansia agar lansia mampu untuk menerima kondisi dan keadaaan yang telah dialami. Bagi lanjut usia, keluargalah yang merupakan sumber sasaran utama yang paling penting. Berdasarkan data awal yang telah diambil terhadap lanjut usia yang berusia 60 sampai dengan umur 70 tahun ke atas di Kelurahan Kadia Kecamatan Kadia Kota Kendari menyatakan bahwasanya mereka ingin tinggal di tengah-tengah keluarga untuk dapat memperoleh perawatan yang layak.

Penelitian ini bertujuan untuk mengetahui kondisi kesehatan mental lansia di Kelurahan Kadia Kecamatan Kadia Kota Kendari dan bertujuan untuk mengetahui bentuk dukungan keluarga dalam menjaga kesehatan mental lansia di Kelurahan Kadia Kecamatan Kadia Kota Kendari.

\section{METODE}

Penelitian yang digunakan dalam penelitian ini adalah penelitian deskriptif dengan pendekatan kualitatif. Menurut Whitney (dalam Nazir, 2003) bahwa penelitian deskriptif merupakan penelitian dengan tujuan untuk pencarian data yang tepat. Sedangkan menurut Bodgan dan Taylor dalam (Sujarweni, 2014) penelitian kualitatif adalah penelitian yang bermaksud untuk memahami fenomena atau gejala sosial dengan cara memberikan pemaparan berupa penggambaran yang jelas tentang fenomena atau gejala sosial tersebut dalam bentuk rangkaian kata yang apada akahirnya akan menghasilkan sebuah teori. Penelitian ini dilaksanakan di Kelurahan Kadia Kecamatan Kadia Kota Kendari. Penelitian ini dilakukan selama 1 bulan. Informan penelitian ini adalah keluarga lansia mencakup dukungan anak kandung yang berjumlah 3 orang, menantu yang berjumlah 3 orang, cucu yang berjumlah 1 orang, dan lansia itu sendiri 
yang berjumlah 10 orang yang berusia 60 sampai dengan 80 tahun. Sumber informasi yang penting tentang sesuatu yang akan diteliti, yaitu data primer, data primer merupakan data yang dikumpulkan melalui pihak pertama. Yaitu dari pihak lansia. Data primer yang dibutuhkan dalam penelitian ini meliputi karakteristik, bentuk dukungan keluarga dan responden dalam penerimaan diri sebagai lansia, menjalin hubungan dengan orang lain, beraktivitas sesuai dengan kemampuannya dan menyesuaikan diri dengan stressor lingkungan. Data sekunder, data sekunder merupakan data yang dikumpulkan melalui pihak kedua. Pihak kedua dalam penelitian ini antara lain keluarga dan sumber informan lainnya yang mengetahui kondisi lansia tersebut. Teknik pengumpulan data, pengumpulan data merupakan langkah yang strategis dalam penelitian, karena tujuan utama dari penelitian adalah mendapatkan data. Tanpa teknik pengumpulan data, maka peneliti tidak berhak mendapatkan data yang memenuhi standard data yang ditetapkan. Pengumpulan data dapat dilakukan dalam berbagai setting, berbagai sumber dan berbagai cara. Apabila dilihat dari settingnya, data dapat dikumpulkan pada setting ilmiah (natural setting). Apabila dilihat dari sumber datanya, maka pengumpulan data dapat menggunakan sumber primer dan sumber sekunder. Selanjutnya apabila dilihat dari segi cara atau tehnik pengumpulan data dapat dilakukan sebagai berikut: wawancara, pengamatan (observasi), dokumentasi. Adapun teknik analisis data yang digunakan dalam peneltian ini yakni reduksi data (data reduction), penyajian data (data display), penarikan kesimpulan / verifikasi (conclusion drawing/verificati).

\section{PEMBAHASAN}

\section{Kondisi Kesehatan Mental Lansia}

Kondisi merupakan suatu situasi atau keadaan yang telah dialami oleh individu baik itu diluar maupun didalam dirinya sendiri. Berdasarkan hasil penelitian yang telah diperoleh, jumlah lansia yang ada di Kelurahan Kadia terdapat 10 orang lansia yang masih tinggal bersama dengan keluarga, diantaranya anak kandung, menantu, dan cucu dari lansia. Diantara 10 orang lansia terdapat 7 orang lansia yang memiliki mental yang rendah yakni diantaranya teradapat 4 lansia suami dan istri yang sama-sama memiliki perasaan kecemasan. Selanjutnya teradapat 2 lansia suami dan istri, 2 orang yang memililiki perasaan yang sangat mudah kelalahan, dan 1 orang yang sangat mudah memiliki perasaan mudah tersinggung. Dan Selebihnya informan lansia yang ada di Kelurahan Kadia memiliki mental yang sehat karena masih dapat untuk menyesuaikan diri secara konstruktif pada kenyataan yang telah dialami dalam kehidupan sehari-hari, 
memperoleh kepuasan dari jerih payah usahanya dengan menjual sayur dan menjual sembako. Adapun penjabaran dari kondisi lansia yakni:

\section{a. Perasaan Kecemasan}

Kecemasan adalah perasaan takut yang tidak jelas dan tidak didukung oleh situasi. Ketika merasa cemas, individu tidak merasa nyaman atau takut atau mungkin memiliki firasat akan ditimpa malapetaka padahal ia tidak mengerti mengapa emosi yang mengancam tersebut terjadi. Tidak ada objek yang dapat diidentifikasi sebagai stimulus kecemasan. Videbeck (dalam Hanifullah, 2015).

Lansia selalu cemas atas keadaan yang telah dialami oleh istrinya yang sudah tidak mampu untuk melakukan aktivitas seperti sediakala. Dan seorang lansia selalu khawatir terhadap kesehatan kakinya yang sudah tidak mampu untuk berjalan. Hal ini dapat menyebabkan kesehatan mental lansia terganggu karena faktor kecemasan yang telah dialami.

\section{b. Mudah Merasa Kelelahan}

Kelelahan adalah perpaduan dari wujud penurunan fungsi mental dan fisik yang menghasilkan berkurangnya semangat kerja hingga mengakibatkan efektifitas dan efesiensi kerja menurun (Saito dalam Ariani, 2009).

Untuk melakukan aktivitas sesuai dengan kemampuannya, lansia sudah mampu untuk banyak melakukan aktivitas karena kondisi lansia yang mudah untuk merasakan kelelahan, seperti seorang lansia yang sebentar berbaring ditempat ketika perasaan lelah itu tiba dan hanya mampu menahan perasaan lelah itu. Kemudian seorang lansia juga tidak bisa melakukan banyak hal, segala pekerjaan anggota keluarga yang mengerjakan semuanya karena lansia sangat mudah merasakan kelelahan. dan lansia hanya mampu merasa pasrah atas keadaan yang sedang dialami meskipun keadaan itu sangat buruk bagi lansia.

\section{c. Mudah Merasa Tersinggung}

Mudah merasa tersinggung merupakan perasaan sakit hati kepada orang lain akibat memiliki emosi yang sangat tinggi, oleh karena itu emosi merupakan salah satu aspek berpengaruh pada tingkah laku manusia. Perasaan yang seperti ini sangat mudah dirasakan oleh lansia yang memiliki perasaan yang sensitive dan merupakan dampak terhadap penurunan mentalnya.

Lansia selalu bersyukur atas keadaan yang sedang dirasakan karena dimana sebagai manusia yang pernah muda tidak akan pernah menghindari usia tua. Disamping 
itu lansia memiliki emosi yang tinggi yang dapat menimbulkan perasaan tidak enak hati kepada orang lain yang mengganngu apa yang lansia sudah anggap nyaman seperti pada saat pembongkaran kiosnya.

\section{d. Mental yang Sehat}

Mental yang sehat menunjukkan kemampuan untuk mengatasi masalah secara efektif dan mengelola stress kehidupan dalam upaya untuk mencapai keadaan emosional yang seimbang. Lanjut usia memiliki keuntungan lebih dari pada kelompok usia lainnya dalam mengatasi pemecahan masalah berdasarkan banyak pengalaman yang dialami bertahun-tahun. Hal ini tidak berarti bahwa gangguan mental tidak menjadi masalah dikalangan lanjut usia (Eliopoulus, 2003).

Meskipun lansia tinggal bersama dengan keluarga namun, lansia memiliki sifat yang mandiri dimana segala tugas-tugas atau kewajiban yang menjadi bebannya, tanpa suka memikul bebannya kepada orang lain dalam kondisi yang tidak terpaksa. Kemudian lansia masih mampu unutk menyesuaikan diri terhadap stressor lingkungan tanpa tekanan seperti masalah yang ada dalam keluarga, dan selanjutnya lansia masih dapat menyesuaikan diri terhadap kehidupan yang nyata, meskipun kenyataan itu buruk baginya.

\section{Bentuk Dukungan Keluarga dalam Menjaga Kesehatan Mental Lansia}

Keluarga merupakan suatu kelompok unti terkecil di dalam masyarakat dan juga merupakan suatu bentuk sistem yang di dalamnya saling terkait dan mempengaruhi antara satu yang lain. Dukungan keluarga dapat berupa kesempatan bercerita, meminta pertimbangan, bantuan atau mengeluh bilamana sedang mengalami persoalan pribadi. Seorang lansia akan mengembangkan perasaan dicintai, dihargai keberadaannya dan ditolong oleh sumber-sumber dukungan keluarga, sehingga dapat menjalani kehidupan dengan wajar.

Selain itu, dukungan keluarga dapat berupa tindakan yang diberikan oleh lansia dalam bentuk nyata berupa cinta kasih, perlindungan, dan sosialisasi dan lain sebagainya yang dapat mendukung kesehatan lansia. dukungan sosial keluarga terhadap lansia mengacu pada dukungan-dukungan yang dipandang oleh anggota keluarga sebagai suatu yang dapat diakses atau diadakan untuk keluarga.

Lansia yang ada di Kelurahan Kadia jika ditinjau dari segi jasmanai, ada diantara mereka masih kuat dalam aktivitas-aktivitasnya dan adapula yang sangat capat merasakan kelelahan sedangkan ditinjau dari segi rohani, lansia ini sangat memiliki fikiran yang sensitif, mudah merasa tersinggung, memiliki perasaan kecemasan yang 
menyebabkan mental yang rendah namun dengan dukungan keluarga dan orang sekitar memberikan perhatian terhadap lansia sehingga dapat melalui hari-harinya dengan baik dan tingkat kesehatannya mentalnya selalu dalam keadaan yang baik. Adapun bentuk dukungan keluarga dalam menjaga kesehatan mental lansia yakni:

\section{a. Dukungan Informasional}

Keluarga berfungsi sebagai sebuah kolektor dan diseminator (penyebar) informasi tentang dunia. Menjelaskan tentang pemberian saran, sugesti, informasi yang dapat digunakan mengungkapkan suatu masalah. Manfaat dari dukungan ini adalah dapat menekan munculnya suatu stressor karena informasi yang diberikan dapat menyumbangkan aksi sugesti yang khusus pada individu. Aspek-aspek dalam dukungan ini adalah nasehat, usulan, saran, petunjuk dan pemberian informasi.

Keluarga memiliki dukungan informasi yang baik kepada lansia, meskipun lansia terkadang menutupi masalah dari anggota keluarga sehingga, anggota keluarga jarang mengetahui tentang permasalahan apa yang telah dialami oleh lansia kemudian tdak dapat diberikan nasehat untuk menyelesaikan masalahnya tersebut, keluarga tidk pernah berhenti untuk memberikan nasehat. Selain daripada itu untuk memberikan informasi keluarga selalu memperhatikan tentang hal apa yang ingin disampaikan, jika yang ingin disampaiakan merupakan informasi yang dapat membuat lansia merasa tersinggung ketika mendengarkannya maka untuk itu agar tidak membuat lansia merasakan hal tersebut, maka keluarga dengan perlahan membuat lansia agar tetap tenang dan melemah lembutkan cara penyampain masalah kepada lansia. Namun demikian terkadang ada yang disampaikan kepada lansia dengan suara yang lemah lembut, dapat membuat lansia merasa tersinggung pada saat mendengarkannya, oleh karena itu untuk tetap menjaga keadaan lansia agar tidak kelelahan dan tetap dalam keadaan sehat.

\section{b. Dukungan Penilaian}

Keluarga bertindak sebagai sebuah bimbingan umpan balik, membimbing dan menengahi pemecahan masalah, sebagai sumber dan validator indentitas anggota keluarga diantaranya memberikan support, penghargaan dan perhatian. Menurut Maslow dan Mittlemenn (dalam Moeljono, 1999) untuk mencapai jiwa yang sehat dapat dimulai dengan penilaian diri yang positif yaitu bagaimana seseorang melihat dirinya yang berkaitan erat dengan cara berpikir, berperan dan bertindak. Bentuk dukungannya dapat dengan memberikan perhatian dalam menghadapi ketidakpercayaan diri lansia, 
menjadikan lansia sebagai tempat bertanya bila keluarga mengalami masalah dan memberikan pemahaman positif tentang perubahan kondisi lansia saat ini.

Ketika ada suatu masalah yang telah dihadapi oleh keluarga, keluarga selalu meminta pendapat kepada lansia namun lansia sudah tidak ingin terlalu ikut campur dengan masalah yang ada dengan tanggapan bahwa dengan usia yang seperti ini, tidak mungkin lansia dapat menyelesaikan masalah yang ada. Namun keluarga selalu memberikan dukungan seperti selalu memberikan semangat kepada lansia agar lansia tidak merasa loyo, serta keluarga selalu mengajak lansia untuk bercanda agar lansia tida merasa bosan. Selain itu keluarga selalu memperhatikan pola makan lansia. Keluarga selalu memberikan perhatian dengan penuh kasih sayang kepada lansia dengan tujuan agar lansia selalu memiliki perasaan yang positif.

\section{c. Dukungan Instrumental}

Keluarga merupakan sebuah sumber pertolongan praktis dan konkrit, diantaranya kesehatan penderita dalam hal kebutuhan makan dan minum, istirahat serta terhindarnya penderita dari kelelahan. Salah satu manifestasi mental yang sehat (secara psikologis)). Berdasarkan pengertian tersebut, maka dukungan keluarga dapat berupa pemenuhan gizi lansia, perhatian terhadap kondisi fisik atau penyakit yang diderita oleh lansia, hingga aktivitas fisik yang harus tetap dilakukan oleh lansia untuk menjaga kebugaran tubuhnya. Keluarga diharapkan dapat memberikan sarana pra sarana dalam menjaga kesehatan fisik dan mental lansia. Sehingga lansia tetap dapat menikmati hidupnya dengan kondisi fisik dan mental yang sehat.

Keluarga selalu memberikan dukungan kepada lansia seperti halnya pemenuhan gizi lansia, dalam pemenuhan gizi pada lansia keluarga memberikan makanan sayuran, ikan serta makanan yang lain yang mengandung gizi, sedangkan untuk pemenuhan kondisi fisik keluarga memeberikan nasehat kepada lansia untuk jalan-jalan di halaman dengan tujuan untuk menjaga kebugaran tubuh lansia. Keluarga selalu memberikan perhatian terhadap kondisi fisik dan mental lansia.

\section{d. Dukungan Emosional}

Keluarga sebagai tempat yang aman dan damai untuk istirahat dan pemulihan serta membantu penguasaan terhadap emosi. Aspek-aspek dari dukungan emosional meliputi dukungan yang diwujudkan dalam bentuk afeksi, adanya kepercayaan, perhatian, mendengarkan dan didengarkan. Seperti yang dikemukakan oleh Hobfoll dalam Niven (2002), bahwa stres dipermudah oleh kehilangan, terancam kehilangan dari sumbersumber baik personal, fisik atau fisiologis. Sehingga dalam penanganan masalah stres 
pada lansia perlu adanya dukungan yang berhubungan dengan faktor-faktor personal dan jaringan sosial.

Keluarga selalu memberikan dukungan emosional kepada lansia seperti halnya keluarga dengan sepenuhnya percaya kepada lansia dengan berbagai hal karena dengan memberikan kepercayaan kepada lansia itu dapat mengurangi perasaan-perasaan negatif yang dimiliki oleh lansia yang akan mengganggu perasaan emosional pada lansia. Namun, terkadang lansia tidak mau bercerita kepada keluarga ketika lansia sedang menghadapi masalah denga alasan bahwa cukup lansia saja yang tau masalahnya dan menyelesaikan masalah itu sendiri tanpa harus menyampaikannya kepada orang lain dan membuat orang lain merasa khawatir, tapi sebagai keluarga tentu akan selalu memberikan saran kepada lansia untuk bercerita ketika ada masalah yang dihadapi, kadang lansia mendengarkan dan kadang pula lansia tidak mendengarkan.

\section{PENUTUP}

Keluarga sebagai poros pencipta ketenangan dan kasih sayang, memiliki tempat istimewa dalam Islam. Orang tua dan keluarga punya peran dominan dalam rumah tangga untuk memberi bimbingan, petunjuk, perhatian, dan kasih sayang kepada keluarganya sehingga dengan demikian dapat mendukung terhadap kesehatan lansia dengan sangat baik. Lansia merupakan seseorang yang memasuki umur 60an ke atas sebagaimana diketahui bahwasanya lansia sudah memasuki umur sekian sangat rentan terhadap penyakit termasuk pada kesehatan mental lansia yang sangat mudah merasa strees dan merasa tidak nyaman terhadap kondisi yang sedang dialami, namun dengan berdasar pada dukungan suatu keluarga yang menjadi dukungan yang sangat berarti bagi lansia, itu akan menjadi suatu pemerhatian khusus yang akan lansia rasakan dengan tampa merasakan stressor lingkungan yang ada.

Kesehatan lansia sangatlah penting untuk selalu diperhatikan baik itu seperti kesehatan badan, rohani dan sosial bukan keadaan yang bebas dari penyakit, namun dengan pemerhatian tersebut dapat mencegah akan terjadinya masalah mental terhadap lansia oleh karena itu berdasarkan hasil penelitian dan pembahasan yang telah dilakukan pada penelitian ini, yaitu untuk mengetahui Bentuk Dukungan Keluarga dalam Menjaga Kesehatan Mental Lansia di Kelurahan Kadia Kecamatan Kadia Kota Kendari maka dapat disimpulkan sebagai berikut : Berdasarkan hasil penelitian diperoleh dari lapangan yaitu sebagian besar lansia mendapatkan dukungan informasi, dukungan penilaian, dukungan instrumental, dan dukungan emosional. Semua dukungan tersebut sangatlah baik, dengan demikian kesehatan mental lansia tetap terjaga dengan baik dan tercipta kesejahteraan dalam keluarga. 


\section{DAFTAR PUSTAKA}

Amalia, et al., 2017. Indikator Praktik Sehat secara Mental pada Lanjut Usia berdasarkan Dukungan Sosia Keluarga. Jurnal Kesehatan. 5(3)

Ariani, N,D. 2009. Tinjauan Faktor Kelelahan Kerja. Skripsi. Universitas Indonesia

Biro Pusat Statistik. 2019. Sulawesi Tenggara Dalam Angka 2010. Kendari. Biro Pusat Statistik Sulawesi Tenggara .

Cutrona, C.E, et al. 1994. Persepsi dukungan sosial orang tua dan akademik prestasi: perspektif teori lampiran. Jurnal Kepribadian dan Psikologi Sosial. 66, 2, 369

Eliopoulos, C. 2003. Geranatological Nursing sixth edition. Philadelpha: Lippincott Williams \& Wilkins

Fauzi. 2014. Usaha Transfortasi Anaka Jalanan Keluar Dari Posisi Anak Jalanan. Skirpsi. Universitas Pendidikan Indonesia

Hanifullah, J. 2015. Perbedaan Efektifitas Terapi Musik Religi dan Terapi Murrotal al quran. Skripsi. Universitas Muhammadiyah Pajajaran

Moeljono N. 1999. Kesehatan Mental Konsep \& Penerapan, (Penerbit Universitas Muhammadiyah Malang, Malang).

Nazir, Muhammad. 2003. Metode Penelitian. Ghalia Indonesia. Jakarta. Hlm. 193-194

Niven, N. 2002. Psikologi Kesehatan, Pengantar untuk Perawat dan Profesional Kesehatan Lain. Alih Bahasa: Agung Waluyo

Nurmalasari. 2010. Bentuk Dukungan Keluarga Terhadap Sikap Lansia Dalam Menjaga Kesehatan Mentalnya. Skripsi. Universitas Jember

Nugroho, Wahyudi. 2009. Keperawatan Gerontik dan Geriatrik Edisi 3. EGC. Jakarta.

Puspita, PGC. 2011. Pengaruh Paparan Debu-Debu Terhadap Gangguan FAAL Paru Pada Pekerja Kontrak Bagian Coal Handing. Skripsi. Universitas Jember

Sujarweni,W,V. 2014. Metode Penelitian. Yogyakarta. PUSTAKABARUPRESS.

Sugiyono, 2007 . Statistika untuk Penelitian. Bandung: Alfabeta.

Tuwu, D., Bahtiar, B., Supiyah, R., \& Upe, A. (2020). Pemberian Dukungan Psikososial

Pada Anak Yang Mengalami Gangguan Di Era Pandemi Covid-19. Journal

Publicuho, 3(3), 394-404. https://doi.org/10.35817/jpu.v3i3.14489

Undang-Undang Republik Indonesia Nomor 23 Tahun 1992 Tentang Kesehatan

Wafroh, Siti, dkk.2016 Dukungan Keluarga dengan Kualitas Hidup Lansia. Jurnal Dunia Keperawatan. 4(1):60-64

World Health Organization, 2013. Mental Health and Older Adults. Available. 